\title{
PENGARUH LATIHAN KONVENSIONAL DAN AKUATIK PADA PEMULIHAN KEMAMPUAN MOTORIK PENYANDANG HEMIPARESIS PASCA STROKE INFARK
}

\author{
Bambang Trisnowiyanto \\ Kementerian Kesehatan Politeknik Kesehatan Surakarta Jurusan Fisioterapi
}

\begin{abstract}
Conventional, Aquatic, Motoric Skill, Hemiparetic, Infarction Stroke. Research objective is to knows how the effects of aquatic training with conventional training to increase motoric skill of hemiparetic patients suffered from infarction stroke. They have got intensive care in Dr. Muwardi Hospital of Surakarta in 2012. These quasi experiment research by design; two group pretestposttest design, with purposive sampling. Treatment; twice perweek for 6-week intervention. Subjects are 15 men, 5 women with hemiparetic post infarction stroke that have no complicated diseases (41-65 years old). Analyzed based on aquatic group $(n=9)$ and conventional group $(n=11)$ ordering by age match subject ordinal pairing assigned. Results of the anlysis both of aquatic and conventional training have got influnce to increase motoric skill of hemiparetic patients that caused by infarction stroke $P=0,000(\alpha=0,05)$. The aquatic training has got influnce more than and conventional to increase motoric skill of hemiparetic patients that caused by infarction stroke. Thus these findings indicate that aquatic exercise benefits people with hemiparesis and can be used as a method of exercise rehabilitation for these people.
\end{abstract}

Keywords: Conventional, Aquatic, Motoric Skill, Hemiparetic, Infarction Stroke

\begin{abstract}
Abstrak: Konvensional, Akuatik, Kemampuan Motorik, Hemiparesis, Stroke Infark. Tujuan penelitian, untuk mengetahui besar pengaruh latihan fisik terhadap pemulihan kemampuan motorik penyandang hemiparesis yang diakibatkan stroke infark fase recovery. Sampel adalah pasien pasca stroke yang telah selesai menjalani masa perawatan intensif di Rumah Sakit Dr. Muwardi Surakarta pada tahun 2012. Jenis penelitian, quasi experiment research dengan rancangan two group pretest-posttest design, penentuan purposive sampling dengan kriteria inklusi. Intervensi latihan 2 kali perminggu selama 6 minggu. Sampel terdiri 15 laki-laki dan 5 perempuan dengan hemiparesis $($ kanan $=12$, kiri=8) pasca stroke infark yang tidak disertai komplikasi penyakit lain. Rentang usia 40 tahun hingga 65 tahun. Analisis didasarkan kelompok latihan akuatik $(n=11)$ dan kelompok latihan konvensional $(n=9)$ dengan urutan usia (match subject ordinal pairing). Hasil analisis; latihan konvensional dan akuatik memberikan pengaruh terhadap pemulihan kemampuan motorik penyandang hemiparesis pasca stroke infark, $\mathrm{P}=0,000 \quad(\alpha=0,05)$. Latihan akuatik memberikan pengaruh lebih besar dibandingkan latihan konvensional terhadap pemulihan kemampuan motorik penyandang hemiparesis pasca stroke infark. Dengan demikian temuan ini memberikan indikasi bahwa latihan akuatik bermanfaat bagi orang dengan hemiparesis dan dapat dijadikan metode olahraga rehabilitasi untuk orang-orang tersebut.
\end{abstract}


Kata Kunci: Konvensional, Akuatik, Kemampuan Motorik, Hemiparesis, Stroke Infark

\section{PENDAHULUAN}

Kemampuan motorik seseorang dalam melakukan aktivitas sehari-hari sangat dipengaruhi oleh:

Kesimbangan, (2) Koordinasi, (3) Fleksibilitas dan mobilitas, (4) Kekuatan dan Ketahanan otot, (5) Kontrol neuromuskuler, (6) Kontrol postural dan stabilitas postural (Kisner, 2007).

\section{Pulihnya}

penyandang hemiparesis akan diawali dengan mampu duduk, berdiri dan berjalan secara mandiri tanpa alat bantu (Gofir, 2009). Untuk mencapai tujuan tersebut umumnya menggunakan pendekatan latihan gerak konvensional (Cheng et al., 2001) berupa latihan neurofasilitasi seperti metode: (1) Bobath (Bertha, 1990), (2) Proprioceptif Neuromuscular Fascilitation (PNF) dari Kabath, Brunnstrom, Knott and Voss (Bogousslavsky, 2005), (3) Motor Relearning Programe (MRP) dari Rood, Johnstone (Johnstone, 1987 dan 1991), (4) Constraint Induced Movement Therapy (CIMT) dari Edward Taub (Irfan, 2010), dan (5) Neuro Development Treatment (NDT) (Edwards, 2002), serta (6) Tehniktehnik fasilitasi aktivitas fungsional dan rekreasi (Harrison, 1995; dan Irfan, 2010).

Namun beberapa metode
latihan pasca stroke yang ada,
umumnya diberikan di atas tempat
tidur dengan asumsi bahwa
penyandang hemiparesis mengalami
kesulitan untuk berdiri tegak dengan
kuat dan seimbang akibat adanya
kelemahan otot pada separuh sisi
tubuh. Ketidakmampuan berdiri
sebetulnya dapat diatasi dengan

menempatkan penderita di dalam air dengan landasan beberapa hukum fisika zat cair.

Umumnya latihan akuatik dilakukan pada fase kronis (setelah enam bulan pasca stroke) dan subjek sudah mampu beraktivitas secara mandiri (Lee, 2010; dan Park et al., 2011). Namun proses untuk mencapai kemampuan beraktivitas secara dini dengan memberikan program latihan akuatik pada fase sub-akut (setelah dua minggu hingga enam bulan pasca stroke) belum dapat ditemukan. Untuk itulah penelitian ini dilakukan dengan tujuan untuk memperoleh informasi, mengkaji dan membuktikan pengaruh latihan konvensional dan akuatik pada pemulihan kemampuan motorik penyandang hemiparesis pasca stroke infark.

Kekuatan otot menurut Wuest and Bucher (2009) merupakan komponen dasar untuk dapat melakukan aktivitas fisik sehari-hari secara fungsional seperti duduk, berdiri, dan berjalan. Kekuatan menurut Lubis (2012) adalah sebagai kemampuan sistem neuromuskular untuk menghasilkan sejumlah tenaga, sehingga mampu melawan tahanan eksternal. Otot yang kuat memberi dukungan stabilisasi dan keseimbangan di samping akan mampu melakukan gerakan yang spesifik, sehingga untuk memperoleh kekuatan otot yang optimal diperlukan program latihan tertentu yang disesuaikan dengan kondisi fisik dan tujuan latihan (Wuest and Bucher, 2009; dan Lubis, 2012).

Program latihan fisik yang disusun bertujuan untuk meningkatkan kekuatan otot sebab kekuatan otot 
menurut Lubis (2012) akan menentukan kemampuan biomotor lain seperti daya tahan, keseimbangan, kecepatan dan koordinasi gerak, sehingga secara fungsional tingkat kekuatan otot tertentu akan mempengaruhi kemampuan fungsional motorik sehari-hari seperti duduk, berdiri dan ambulasi. Secara umum, tujuan latihan fisik menurut Bompa (1994) adalah untuk meningkatkan komponen biomotor yang meliputi: (1) Kekuatan, (2) Ketahanan,

Kecepatan, (4) Koordinasi dan (5) Fleksibilitas.

Terdapat beberapa alasan yang mendasari pemberian program latihan fisik yang sangat penting bagi pemulihan kemampuan motorik pasca stroke, diantaranya adalah: (1) Teori plastisitas sel otak dari Carr and Shepherd (1998), (2) Rekomendasi American Heart Association mengenai program latihan fisik pasca stroke, dan (3) Hasil-hasil penelitian mengenai latihan fisik pasca stroke.

\section{METODE PENELITIAN}

Jenis penelitian quasi experimental research atau penelitian eksperimental semu, karena penelitian ini belum atau tidak memiliki ciri-ciri rancangan penelitian sebenarnya, karena variabel-variabel yang seharusnya dikontrol atau dimanipulasi tidak dapat atau sulit dilakukan, sehingga validitas penelitian ini kurang cukup untuk disebut penelitian yang sebenarnya.

Populasi dalam penelitian ini adalah semua penderita hemiparesis pasca stroke infark cerebri fase subakut (antara 2 minggu-6 bulan pasca stroke) yang telah selesai menjalani masa perawatan intensif pada unit stroke di Rumah Sakit. Adapun penentuan diagnosis stroke infark cerebri dilakukan oleh dokter ahli saraf (neurolog) melalui pencitraan pembuluh darah di otak dengan x-ray computed tomography (CT-Scan) maupun dengan magnetic resonance imaging (MRI). Infark cerebri adalah diagnosis medis berdasarkan international statiktical classification of disease and related health problem (ICD-RHP) yang diterbitkan oleh WHO pada tahun 2004.

Rancangan disertasi yang digunakan adalah Two Group Pretes Posttest Design (Nasir, 2011).

\section{Pretest}

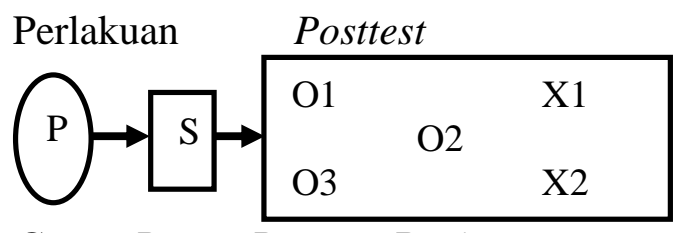

Group Pretes Posttest Design.

Keterangan:

$\mathrm{P} \quad=$ Populasi

$\mathrm{S} \quad=$ Sampel

$\mathrm{O} 1=$ Pretest Kelompok

Konvensional

O2 =Posttest Kelompok

Konvensional

$\mathrm{O} 3=$ Pretest Kelompok Akuatik

O4= Posttest Kelompok Akuatik

$\mathrm{X} 1=$ =Perlakuan Latihan

Konvensional

X2 = Perlakuan Latihan Akuatik

Definisi operasional variabel penelitian adalah uraian tentang batasan variabel yang diukur dan digunakan dalam penelitian bersangkutan (Notoatmodjo, 2012). Variabel yang digunakan dalam penelitian disertasi disini adalah terdiri dari:

a. Variabel bebas (independent variable) yaitu variabel yang mempengaruhi variabel lain. Variabel bebas dalam penelitan 
disini adalah latihan konvensional dan latihan akuatik.

b. Variabel terikat (dependent variable) yaitu variabel yang dipengaruhi oleh variabel bebas. Variabel terikat dalam penelitan disini adalah kemampuan motorik yang terdiri dari kekuatan otot, keseimbangan duduk, keseimbangan berdiri dan kemampuan ambulasi.

c. Variabel pengganggu (confounding variable) yaitu variabel yang mengganggu terhadap hubungan variabel bebas dan variabel terikat. Variabel pengganggu dalam penelitan disini antara lain: (1) Jenis kelamin, (2) Usia, (3) Sisi lesi, dan (4) Lama rawat inap.

Data hasil pengukuran kemampuan motorik dalam penelitian ini adalah berupa kriteria nilai yang bertingkat atau berjenjang dengan mempunyai nilai nol absolut, sehinga berdasarkan uraian tersebut di atas, jenis data kontinum dalam penelitian ini adalah jenis data ordinal.

Analisis data pada penelitian disertasi ini akan dilakukan 2 tahap, yaitu: (1) Uji pengaruh tahap 1: untuk mengetahui adanya pengaruh latihan konvensional dan akuatik terhadap pemulihan kemampuan motorik, uji pengaruh tahap 1 ini menggunakan uji paired samples t-test, (2) Uji pengaruh tahap 2: untuk mengetahui besarnya pengaruh kedua program latihan terhadap kekuatan otot dan besarnya pengaruh kekuatan otot terhadap pemulihan kemampuan motorik yang terdiri dari keseimbangan duduk, keseimbangan berdiri dan kemampuan ambulasi pada kedua kelompok latihan. Pada uji pengaruh tahap 2 ini, menggunakan uji regresi multivariate analysis of variance atau general linear model.

\section{HASIL PENELITIAN}

Pada penelitian disertasi ini diteliti sebanyak 20 orang penderita pasca stroke dengan diagnosis tunggal infark cerebri akibat thrombosis pada arterial cerebri sebagai sampel penelitian. Diagnosis infark cerebri adalah berdasarkan hasil pencitraan pembuluh darah di Otak dengan $x$-ray computed tomography (CT-Scan) maupun dengan magnetic resonance imaging (MRI) yang ditentukan oleh dokter ahli saraf (neurolog) yang bertugas di Rumah Sakit Dr. Muwardi Surakarta.

Penamaan diagnosis infark cerebri akibat thrombosis pada arterial cerebri dengan kode 163.3 ini berdasarkan international statiktical classification of disease and related health problem, yang diterbitkan oleh WHO pada tahun 2004.

Adapun mekanisme mendapatkan sampel penelitian sebanyak 20 orang adalah sebagai berikut; jumlah seluruh pasien stroke dengan diagnosis infark (kode $=163$ ) yang dirawat di Unit Pelayanan Fungsional (UPF) Neurologi Rumah Sakit Dr. Muwardi Surakarta periode Januari-Desember 2012 (selama 1 tahun) adalah sebanyak 439 orang, kemudian dilakukan identifikasi berkas-berkas catatan medis pada bagian Rekam Medis Rumah Sakit Dr. Muwardi Surakarta.

Dari 439 orang pasien pasca stroke infark cerebri diperoleh 63 orang pasien yang masuk ke dalam kriteria inklusi, metode mendapatkan sampel dengan menggunakan kriteria inklusi ini menurut Sugiyono (2006) disebut dengan purposive sampling. 
Kemudian peneliti mengadakan kunjungan rumah atau visitasi kepada 63 orang tersebut.

Dari hasil kunjungan rumah diperoleh 23 orang yang bersedia untuk menjadi sampel penelitian, dari 23 orang ini kemudian dialokasikan secara match subject ordinal pairing berdasarkan urutan usia sampel menjadi 2 kelompok yang terdiri dari; 12 orang pada kelompok konvensional dan 11 orang pada kelompok akuatik. Setelah sampel terbagi menjadi 2 kelompok, kemudian kedua kelompok tersebut menjalani latihan sebanyak 2 kali/minggu selama 6 minggu pada masing-masing latihan. Dalam proses menjalani latihan konvensional dan akuatik, dari 23 orang sampel tersebut, terdapat beberapa orang sampel yang gugur (drop-out) yaitu; 1 orang dari kelompok konvensional dan 2 orang dari kelompok akuatik. Sehingga sampel yang benar-benar diteliti adalah sebanyak 20 orang yang terdiri dari; 11 orang sampel dari kelompok konvensional dan 9 orang dari kelompok akuatik.

Sesuai dengan tujuan penelitian, bahwa pemberian program latihan konvensional dan akuatik dalam penelitian ini adalah untuk pemulihan kekuatan otot tungkai dan lengan pada separuh sisi tubuh vertikal (hemiparesis) yang diakibatkan oleh serangan stroke infark, dimana kondisi kelemahan otot pada tungkai dan lengan ini akan mempengaruhi kemampuan motorik, maka analisis data dalam penelitian ini dilakukan 2 tahap yaitu: (1) Uji paired samples ttest untuk mengetahui adanya pengaruh kedua program latihan terhadap pemulihan kemampuan motorik, dan (2) Uji regresi multivariate analysis of variance atau general linear model untuk mengetahui besar pengaruh program latihan terhadap pemulihan kekuatan otot tungkai dan lengan, dan untuk mengetahui besar pengaruh kekuatan otot terhadap pemulihan kemampuan motorik pada kedua program latihan.

Dari hasil uji normalitas data dengan menggunakan KolmogorovSmirnov Test, dapat diketahui bahwa data variabel kemampuan motorik kelompok latihan konvensional dan akuatik yang diuji berdistribusi normal, dimana $P>\alpha,(\alpha=0,05)$.

Adapun distribusi yang tidak memiliki varian, tidak dapat ditampilkan oleh tes KolmogorovSmirnov, yaitu pada nilai probabilitas pretest kemampuan ambulasi dan nilai probabilitas posttest keseimbangan duduk pada kelompok akuatik.

Dari hasil uji normalitas residual dengan menggunakan Kolmogorov-Smirnov Test, dapat diketahui bahwa data variabel kemampuan motorik kelompok latihan konvensional dan akuatik yang diuji, berdistribusi normal, dimana $P>\alpha$, $(\alpha=0,05)$.

Pada analisis regresi multivariate analysis of variance (manova) dengan bantuan program statistical package for the social sciences (SPSS), maka pengujian homogenitas varians secara otomatis akan nampak pada tampilan Levene's test of equality of error variances dengan asumsi jika diperoleh nilai probabilitas lebih besar dari $\alpha=0,05$ $(P>\alpha)$ maka data yang diuji homogen.

\section{PEMBAHASAN}

Sebanyak 23 orang penyandang hemiparesis pasca stroke infark berperan serta sebagai sampel dalam penelitian ini. 23 orang sampel ini 
diperoleh dari hasil penyaringan sebanyak 439 orang penyandang hemiparesis pasca stroke infark melalui kriteria inklusi dan eksklusi, kemudian pembagian kelompok latihan dilakukan secara match subject ordinal pairing menjadi 11 orang sebagai kelompok latihan akuatik dan 12 orang sebagai kelompok latihan konvensional. Sampel yang gugur pada masing-masing kelompok adalah 2 orang dari kelompok latihan akuatik dan 1 orang dari kelompok latihan konvensional. Sehingga jumlah sampel yang mengikuti program latihan secara lengkap sebanyak 20 orang.

Lebih lanjut Hartanto (2009) menjelaskan bahwa insiden stroke akan meningkat secara eksponensial menjadi dua hingga tiga kali lipat setiap dekade di atas usia 50 tahun dan 1 dari 3 orang yang berusia di atas 60 tahun akan menderita salah satu jenis stroke, bahkan Perhimpunan Dokter Spesialis Saraf Indonesia (Perdosi) dalam Guidline Stroke (2011) menyebutkan bahwa penderita stroke laki-laki lebih banyak dibanding perempuan dengan profil usia penderita stroke adalah $11,8 \%$ usia dibawah 50 tahun, 54,2\% diatas 50 tahun dan $33,5 \%$ diatas 65 tahun.

Penelitian Bruno-Petrina (2007) menunjukan bahwa insiden stroke, 19\% lebih tinggi pada pria. Stroke jarang terjadi pada usia kurang dari 50 tahun, tetapi insidensinya meningkat dua kali lipat perdekade setelah usia 55 tahun. Faktor usia yang mempengaruhi terjadinya stroke infark, secara patogenesis dapat dijelaskan bahwa, dinding pembuluh darah yang terdiri dari tunika intima, tunika media dan tunika adventia dalam jaringan otak biasanya sangat tipis walaupun elastis, namun akumulasi perkembangan plak aterosklerotik dalam pembuluh darah tersebut memegang peranan penting dalam terbentuknya oklusi pembuluh arteri oleh thrombosis dan atau emboli yang akan mengakibatkan terganggunya aliran darah otak atau cerebral blood flow ( $C B F$ ) sehingga aktivitas metabolisme oksigen dan glukosa dalam otak akan terhenti yang berujung pada kematian sel-sel neuron (Rosamond 1999, dalam Hartanto 2009).

Kematian sel neuron di otak akibat penyumbatan aliran darah otak inilah yang disebut dengan cerebral infarction atau brain ischemia. Pada stroke infark, suplai darah pada bagianbagian tertentu di otak mengalami penurunan, sehingga akan mengalami disfungsi pada jaringan otak pada area tersebut.

Terdapat 3 alasan mengapa hal tersebut dapat terjadi, yaitu (1) Thrombosis, yaitu keadaan obstruksi pembuluh darah oleh pembentukan plak darah secara lokal, (2) Embolism, yaitu keadaan obstruksi pembuluh darah oleh suatu embolus dari bagian lain dari tubuh, (3) Hypoperfusi Sistemik, yaitu keadaan menurunnya suplai darah tubuh secara general, misalnya pada kondisi shock.

Kemudian pada hasil analisis data dengan menggunakan regresi multivariate analysis of variance, menunjukan hasil bahwa program latihan akuatik memberikan angka ratarata lebih besar dibandingkan latihan konvensional terhadap pemulihan kekuatan otot. Program latihan konvensional dan akuatik memberikan pengaruh sebesar $55,1 \%$ terhadap pemulihan kekuatan otot tungkai, dan $71,1 \%$ terhadap pemulihan kekuatan otot lengan. 
Pada penelitian disertasi ini, pemulihan kekuatan otot pada penyandang hemiparesis pasca stroke diperoleh bukan dari latihan kekuatan otot secara khusus namun merupakan akumulasi latihan gerak yang berulang, yang dimulai dari gerakan yang sederhana seperti menekuk dan meluruskan persendian pada lengan dan tungkai, hingga gerakan yang komplek seperti berdiri dan berjalan.

Pada pelaksanaan latihan akuatik, sampel mendapatkan tahanan dari air pada setiap gerakannya, sehingga otot mendapatkan stimulasi penahanan gerak dibandingkan dengan latihan konvensional yang dilakukan di darat.

\section{KESIMPULAN DAN SARAN}

Berdasarkan hasil analisis dan pembahasan pada penelitian dengan judul "Pengaruh Latihan Konvensional dan Akuatik pada Pemulihan Kemampuan Motorik Penyandang Hemiparesis Pasca Stroke Infark", dapat disimpulkan beberapa hal sebagai berikut;

1. Program latihan konvensional memberikan pengaruh terhadap pemulihan kemampuan motorik penyandang hemiparesis pasca stroke infark.

2. Program latihan akuatik memberikan pengaruh terhadap pemulihan kemampuan motorik penyandang hemiparesis pasca stroke infark.

3. Program latihan akuatik memberikan pengaruh lebih besar dibanding latihan konvensional terhadap pemulihan kemampuan motorik penyandang hemiparesis pasca stroke infark.
Adapun beberapa saran yang dapat disampaikan berdasarkan simpulan tersebut diatas adalah:

1. Program latihan akuatik untuk dapat lebih dikembangkan pemanfaatannya tidak terbatas hanya untuk penyandang hemiparesis pasca stroke yang berjenis infark saja tetapi juga untuk stroke yang berjenis perdarahan.

2. Program latihan akuatik dapat dikembangkan pemanfaatannya untuk pemulihan kondisi disabilitas lain, selain yang disebabkan oleh karena serangan stroke.

3. Program latihan akuatik dapat menjadi salah satu alternatif pengembangan layanan pemulihan kemampuan motorik pada unit-unit rehabilitasi medis bagi penyandang hemiparesis pasca stroke di rumah sakit maupun di panti-panti rehabilitasi fisik lain.

\section{DAFTAR RUJUKAN}

Bertha, B. 1990. Adult Hemiparesis Evaluation and Treatment. Edisi ketiga, Oxford: Butterworth Heinemann.

Bompa, Tq. 1994. Periodization: Theory and Methodology of Training. 5 edition. York University, Champaign: Human Kinetics Books.

Bruno-Petrina. 2007. Motor Recovery in Stroke.

http://emedicine.medscape.com/ article/324386-overview (diunduh 30 April 2011)

Carr, J.H. and Shepherd, R.B. 1998. Neurological Rehabilitation: Optimizing Motor Performance, Oxford: Butterworth-Heinemann. 
Cheng., Pao, T., Wu., and Fuk, T. 2001, Symmetrical Body-Weight Distribution Training in Stroke Patients and Its Effect on Fall Prevention. Taiwan: Chang Gung University.

Edwards, S. 2002. Neurological Physiotherapy: A Problem Solving Approach. Edinburgh: Churchill Livingstone.

Gofir, A. 2009. Manajemen Stroke; Evidence Based Medicine. Cetakan Pertama. Yogyakarta: Pustaka Cendikia Press.

Hartanto, Oemar Sri. 2009. Pencegahan Primer Stroke Iskemik dengan Mengendalikan Faktor Resiko. Universitas Sebelas Maret Surakarta; Pidato Pengukuhan Guru Besar.

Irfan, M. 2009. Keseimbangan Pada Stroke.

http://infostroke.wordpress.com /keseimbangan-pada-stroke/. (diunduh 10 Juni 2010).

Irfan, M. 2010. Fisioterapi bagi Insan Stroke. Yogyakarta: Graha Ilmu.

Johnstone. 1987. The Stroke Patient: A Team Approach. London: Churchill Livingstone.

Johnstone. 1991. Therapy for Stroke. London: Churchill Livingstone.

Kisner., Carolyn. and Colby, L. 1996. Therapeutic Exercise Foundation and Technique. Third edition. Philadelphia: F.A Davis Company.

Lee, D., Ko, T. and Cho, Y. 2010. Effects on Static and Dynamic Balance of Task-Oriented Training for Patients in Water or on Land. South Korea: Journal Physiotherapy Science.

Lee., Gyu, C., Song., Chang, H., Lee., Yong, W., Cho., Hwi, Y., Lee. and Seung, W. 2011. Effects of Motor Imagery Training on gait Ability of Patients with Chronic Stroke. Seoul: Journal Physiotherapy Science.

Lee., Su, K., Lee., Sang, Y., Park., Min, C. and Kim, K. 2011. The Correlation of Gait Velocity, Cadence and Gait Quality Parameter Using Points of Gait Quality Chart (GQC) Items in Hemiplegic Patients. Korea: Journal Physiotherapy Science.

Lubis, J. 2012. Latihan Kekuatan untuk Atlet Muda. FIK Universitas Negeri Jakarta. KONI Pusat. Jakarta.

Nasir, A. 2011. Buku Ajar: Metodologi Penelitian Kesehatan. Konsep Pembuatan Karya Tulis dan Thesis untuk Mahasiswa Kedokteran. Yogyakarta: Nuha Medika.

Park, J., Lee, D., Lee, S., Lee., Chang, L., Yoon, J., Lee, M., Lee, J., Choi., Jong, D., Roh. and Hyo, L. 2011. Comparison of the Effects of Exercise by Chronic Stroke Patients in Aquatic and Land Environments. Korea: Journal Physiotherapy Science.

Sugiyono. 2006. Statiktik untuk Penelitian. Cetakan ke Sembilan. Bandung: Alfabeta.

Wuest, DA., and Bucher, CA. 2009. Foundation of Physical Education, Exercise Science and Sport. Toronto. 